\title{
Comparative study of wing spikers on offensive efficiency actions in obtaining points in high performance competitions
}

\author{
Cristian ȘANTA¹, Radu-Cristian STUPAR ${ }^{2}$
}

\begin{abstract}
The aim of the study is to assess the effectiveness of world-class offensive players over a period of two years, players who have qualified and participated in the Rio 2016 Olympic Games and also in the 2017 Volleyball World League. The variables used for this comparison are: the height of the players, the spot for striking the ball , the number of attacks made in each match, the number of points awarded after attacks, while considering for analysis the outside hitter and opposite positions. High-performance players record 250-300 shares in a 5-set match, about 269 jumps, the center player about 223 jumps, the outside hitter around 197, and the opposite 128 jumps, resulting in an average of 194 jumps, according to Piucco T, Santos S., (2009). Success in sports games especially in high-performance competitions is determined by the mental ability of the player that ensures personal efficiency.
\end{abstract}

Key words: volleyball, outside hitter, strike, hitting efficiency

\section{Rezumat}

Scopul studiului constă în diferențierea eficienței acțiunilor ofensive ale jucătorilor de talie mondială la interval de doi ani care s-au calificat și au participat la Jocurile Olimpice Rio 2016, Liga Mondială la volei 2017. Variabilele comparate sunt: înălțimea jucătorilor, punctul de lovire a mingii, numărul de atacuri realizate în fiecare meci, numărul de puncte realizate din atac, luând în calcul posturile extremă dreapta și extremă stânga.

Jucătorii de înaltă performanță înregistrează 250-300 de acțiuni în cadrul unui meci de 5 seturi, aproximativ 269 de sărituri, jucătorul de centru aproximativ 223 extremele stânga aproximativ 197 și extremele dreapta 128 sărituri realizând o medie de 194 sărituri Piucco T, Santos S., (2009). Succesul în jocurile sportive mai ales în competițiile de mare performanță este determinat de abilitatea mentală a jucătorului care asigură eficiența personală, indicator.

Cuvinte cheie: volei, extremă stânga, atac, eficiență atac

\footnotetext{
${ }^{1}$ Asoc. Prof., Babes Bolyai University, Cluj-Napoca, Romania, Faculty of Physical Education and Sport

${ }^{2}$ PhD Student, University of Babes Bolyai, Cluj-Napoca, Romania, Faculty of Physical Education and Sport, e-mail : stupar_radu@yahoo.com
} 


\section{Introduction}

Volleyball is considered one of the most explosive and fast-running sports. It all started with YMCA Springfield's younger teacher of physical and sports education, Morgan, and will remain in history as the inventor of the volleyball game, at that time being called "Mintonette." Together with the evolution of the game, the rules of the game evolved too, but they are not common in all parts of the world.

A feature of the volleyball game is that each team can have a maximum of three touches, receiving the ball and attack. The volleyball game has a cyclical and sequential structure through which the previous game phase will influence the next one [1]. Two types of actions can be distinguished from the three touches, according to José M. Palao, Manzanares P., Valadés D., [2], the solid or terminal actions that attempt to score, actions that challenge the opposing team and continuous actions aiming at neutralizing, eliminating the possibilities of action for the opposing team.

These actions aimed at neutralizing or eliminating the opponents possibilities may consist in sending the opponent a ball that makes it difficult for him to continue the action or in sending a ball to his teammate to increase the chances or facilitates the obtaining of the next point.

The evolution of volleyball world-wide has led players to specialize in positions with different roles. The specialization of positions in volleyball leads to the classification of players in different types. The player considered the first option to be the opposite or spiker, followed by the outside hitter or the second player. Traditionally the opposite or spiker is the player who is the most involved in the attack phases with the highest possibility of completing an attack (make a kill) either from the front row or back row lineup [3]. Side players must have very good orientation skills and advanced physical abilities to meet the ball transmitted by the setter to the highest possible point in order to initiate the attack.

The effectiveness of attack, block and service actions depend on the height at which they are executed in relation to the height of the net and are determined by the player's ability to raise vertically his center of gravity - improve his jump height [5]. In volleyball the rally is the decisive part of a match. The results accomplished by a team show the effectiveness of the attack, which depends on the characteristics of each team, and the position of the players who have the possibility to attack.

Winning a rally is particular to one player and involves his full participation, using all his physical, technical, tactical and mental capacity as a whole.

\section{Sampling}

The selection of the subjects to analyze for comparison was based on their participation in the two events, namely the Rio 2016 Olympic Games and the Volleyball World League 2017. The teams taking part in the Olympics in Rio, twelve in number, were the same teams who got selected for participation in the World Volleyball Championship 2017.

\section{Materials and methods used}

Data for this study was collected in 2016 during the Olympic Games and in 2017 during the World Cup matches at indoor volleyball. The lot being studied represents a small number of players who participated in both events playing either as outside hitters or opposites. The indicators we examined were: the height of the players, the height of the strike, the height of the block, the effectiveness of the attack, the progress made since the Olympic Games until the World League in the World League (2017). All the attack actions executed by the side players have been recorded as percentage of the success rate in relation to the personal attempts and total attempts of the team.

\section{Results and discussions}

There were a total of 74 matches played in both events, 36 held in the Olympic Games and 36 matches taking place at the World League 2017. The statistical analysis tracked the actions of 8 players from different countries that added up 517 attempts at both events, with 176 attempts at Rio 2016 and 341 at the World League 2017. The players' analysis took into account the number of attempted and completed offensive actions that led to obtaining a point. The percentage of personal successes and successes within the team of the analyzed players showed the following results: 
Table no.1 Average action per game PERRIN John Gordon (P1)

\begin{tabular}{|c|c|c|c|c|c|c|c|}
\hline $\mathbf{H}$ & SH & BH & $\mathbf{E}$ & A & WA & $\begin{array}{c}\% \text { of } \\
\text { team } \\
\text { success } \\
\text { rate }\end{array}$ & $\begin{array}{c}\% \text { of } \\
\text { persona } \\
1 \\
\text { success } \\
\text { rate }\end{array}$ \\
\hline \multirow{2}{*}{201} & \multirow{2}{*}{353} & \multirow{2}{*}{329} & $\begin{array}{c}\text { RIO } \\
16 \\
\end{array}$ & $\begin{array}{c}18,0 \\
4\end{array}$ & 7,06 & $\begin{array}{c}35,33 \\
\%\end{array}$ & $18,81 \%$ \\
\hline & & & $\begin{array}{c}\text { WL } \\
17\end{array}$ & 26 & 11,02 & $\begin{array}{c}27,03 \\
\%\end{array}$ & $40,33 \%$ \\
\hline
\end{tabular}

Table no. 2. Average action per game H. Milad (P2)

\begin{tabular}{|c|c|c|c|c|c|c|c|}
\hline H & SH & BH & E & A & WA & $\begin{array}{c}\text { \% of } \\
\text { team } \\
\text { success } \\
\text { rate }\end{array}$ & $\begin{array}{c}\% \text { of } \\
\text { personal } \\
\text { success } \\
\text { rate }\end{array}$ \\
\hline \multirow{2}{*}{196} & \multirow{2}{*}{350} & \multirow{2}{*}{310} & $\begin{array}{c}\text { RIO } \\
16\end{array}$ & 19,3 & 7,3 & $16,24 \%$ & $34,22 \%$ \\
\cline { 3 - 7 } & & $\begin{array}{c}\text { WL } \\
17\end{array}$ & 26,6 & 12,6 & $23,27 \%$ & $45,03 \%$ \\
\hline
\end{tabular}

Table no.3 Average action per game

L. Ricardo (P3)

\begin{tabular}{|c|c|c|c|c|c|c|c|}
\hline H & SH & BH & E & A & WA & $\begin{array}{c}\text { \% of } \\
\text { team } \\
\text { success } \\
\text { rate }\end{array}$ & $\begin{array}{c}\text { \% of } \\
\text { personal } \\
\text { success } \\
\text { rate }\end{array}$ \\
\hline \multirow{2}{*}{196} & \multirow{2}{*}{348} & \multirow{2}{*}{326} & $\begin{array}{c}\text { RIO } \\
16\end{array}$ & 23,66 & 11,16 & $21,32 \%$ & $49,06 \%$ \\
\cline { 4 - 8 } & & $\begin{array}{c}\text { WL } \\
17\end{array}$ & 28,05 & 13,33 & $23,33 \%$ & $46,45 \%$ \\
\hline
\end{tabular}

Table no. 4 Average action per game

N. Earvin (P4)

\begin{tabular}{|c|c|c|c|c|c|c|c|}
\hline H & SH & BH & E & A & WA & $\begin{array}{c}\text { \% of } \\
\text { team } \\
\text { success } \\
\text { rate }\end{array}$ & $\begin{array}{c}\text { \% of } \\
\text { personal } \\
\text { success } \\
\text { rate }\end{array}$ \\
\hline \multirow{2}{*}{194} & \multirow{2}{*}{358} & 327 & $\begin{array}{c}\text { RIO } \\
16\end{array}$ & 26,04 & 13,04 & $30,26 \%$ & $54,09 \%$ \\
\cline { 3 - 7 } & & $\begin{array}{c}\text { WL } \\
17\end{array}$ & 35,66 & 18,66 & $32,63 \%$ & $51,04 \%$ \\
\hline
\end{tabular}

Table no.5 Average action per game

S. Taylor (P5)

\begin{tabular}{|c|c|c|c|c|c|c|c|}
\hline H & SH & BH & E & A & WA & $\begin{array}{c}\text { \% of } \\
\text { team } \\
\text { success } \\
\text { rate }\end{array}$ & $\begin{array}{c}\% \text { of } \\
\text { personal } \\
\text { success } \\
\text { rate }\end{array}$ \\
\hline \multirow{2}{*}{196} & \multirow{2}{*}{345} & \multirow{2}{*}{320} & $\begin{array}{c}\text { RIO } \\
16\end{array}$ & 22,75 & 10,05 & $18,02 \%$ & $45,66 \%$ \\
\cline { 4 - 8 } & & $\begin{array}{c}\text { WL } \\
17\end{array}$ & 23,06 & 13,08 & $27,58 \%$ & $57,28 \%$ \\
\hline
\end{tabular}

Table no.6 Average action per game K. Michal (P6)

\begin{tabular}{|c|c|c|c|c|c|c|c|}
\hline H & SH & BH & E & A & WA & $\begin{array}{c}\text { \% of } \\
\text { team } \\
\text { success } \\
\text { rate }\end{array}$ & $\begin{array}{c}\% \text { of } \\
\text { personal } \\
\text { success } \\
\text { rate }\end{array}$ \\
\hline \multirow{2}{*}{191} & \multirow{2}{*}{328} & \multirow{2}{*}{312} & $\begin{array}{c}\text { RIO } \\
16\end{array}$ & 19,25 & 9,25 & $18,05 \%$ & $47,66 \%$ \\
\cline { 3 - 8 } & & $\begin{array}{c}\text { WL } \\
17\end{array}$ & 22,33 & 11 & $22,56 \%$ & $47,06 \%$ \\
\hline
\end{tabular}

Table no.7 Average action per game De Souza W. (P6)

\begin{tabular}{|c|c|c|c|c|c|c|c|}
\hline H & SH & BH & E & A & WA & $\begin{array}{c}\text { \% of } \\
\text { team } \\
\text { success } \\
\text { rate }\end{array}$ & $\begin{array}{c}\% \text { of } \\
\text { personal } \\
\text { success } \\
\text { rate }\end{array}$ \\
\hline \multirow{2}{*}{198} & \multirow{2}{*}{344} & \multirow{2}{*}{318} & $\begin{array}{l}\text { RIO } \\
16\end{array}$ & 29 & 14,4 & $30,14 \%$ & $50,62 \%$ \\
\cline { 3 - 8 } & & $\begin{array}{l}\text { WL } \\
17\end{array}$ & 34,33 & 16,33 & $28,31 \%$ & $47,29 \%$ \\
\hline
\end{tabular}

Table no.8 Average action per game

K. Egor (P7)

\begin{tabular}{|c|c|c|c|c|c|c|c|}
\hline H & SH & BH & E & A & WA & $\begin{array}{c}\text { \% of } \\
\text { team } \\
\text { success } \\
\text { rate }\end{array}$ & $\begin{array}{c}\text { \% of } \\
\text { personal } \\
\text { success } \\
\text { rate }\end{array}$ \\
\hline \multirow{2}{*}{208} & \multirow{2}{*}{360} & \multirow{2}{*}{350} & $\begin{array}{c}\text { RIO } \\
16\end{array}$ & 25,75 & 13 & $24,53 \%$ & $50,49 \%$ \\
\cline { 3 - 7 } & & $\begin{array}{c}\text { WL } \\
17\end{array}$ & 25,5 & 11,5 & $26,76 \%$ & $48,27 \%$ \\
\hline
\end{tabular}

Legend: H-Height, SH-Strike Height, BH-Block Height, E-Event, A-Attempts, WA-Won Attempts, \%percentage.

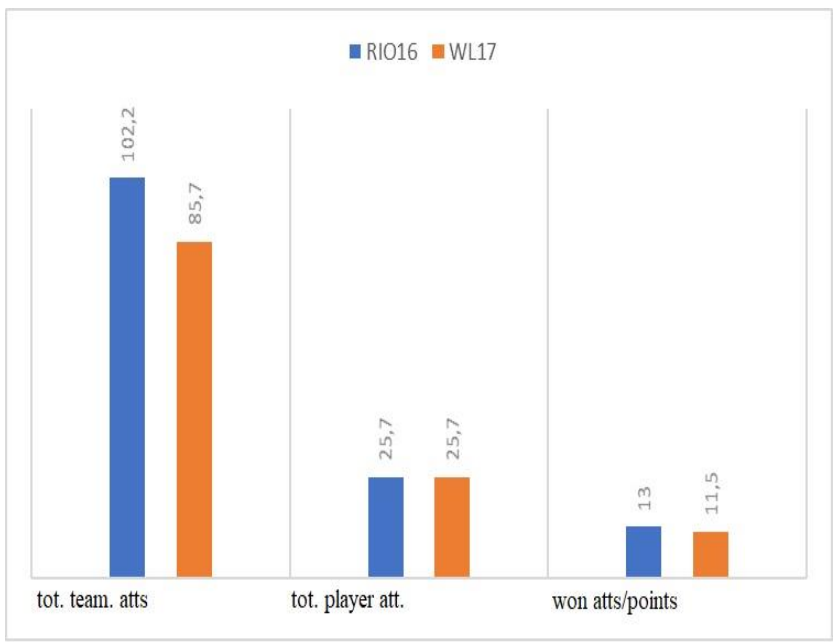

Figure 1.Effectiveness of offensive actions 


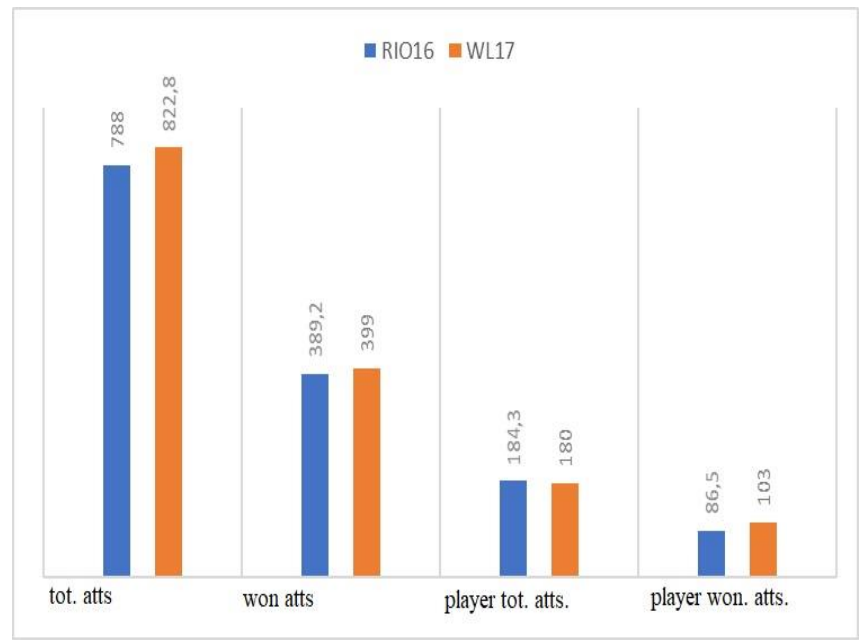

Figure 2.The average of offensive actions distributed on events

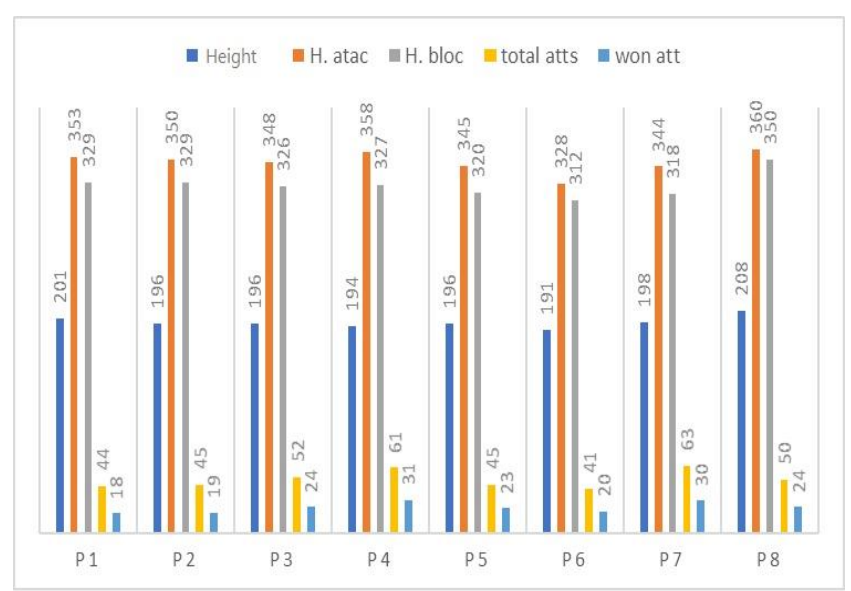

Figure 3. Player results in all events

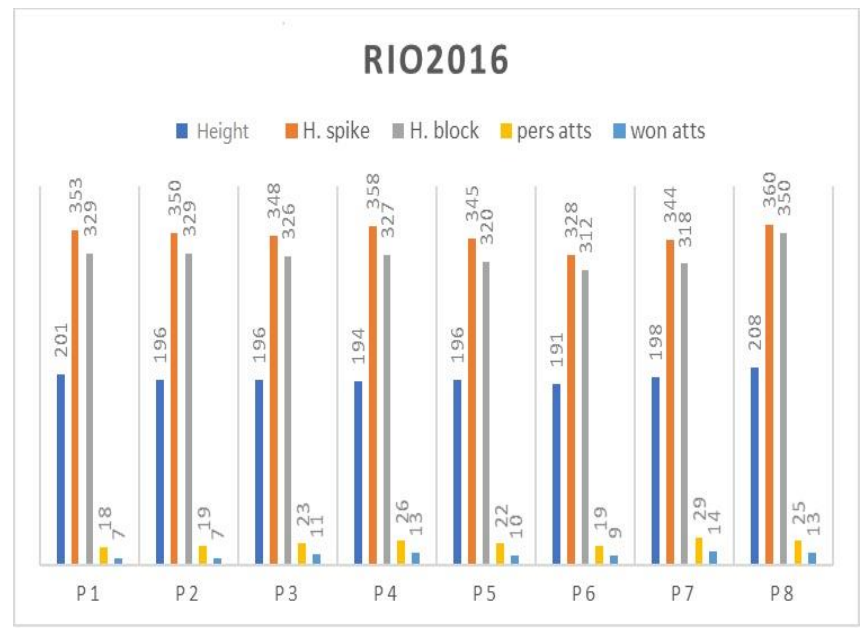

Figure 4. Player results RIO 2016

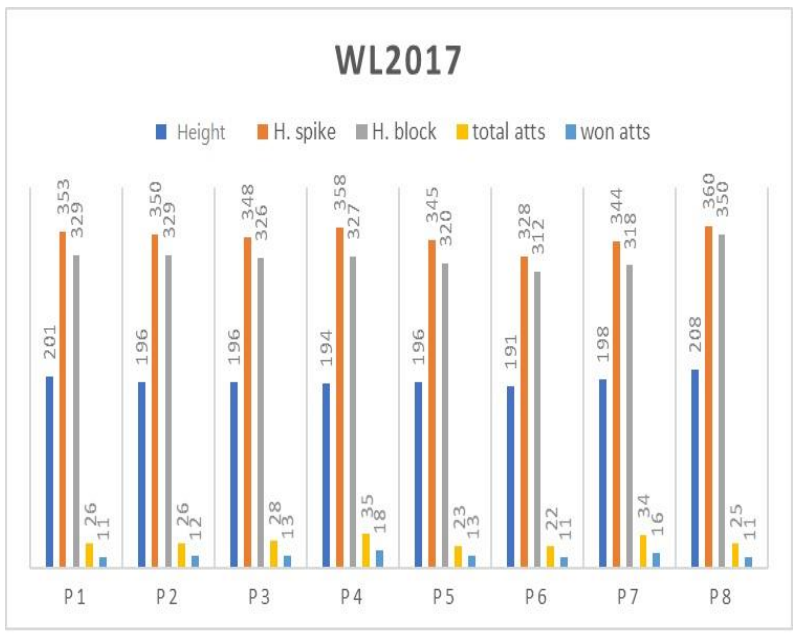

Figure 5. Player results WL2017

Figure no. 3 and no. 4 reveal an increase in the number of offensive actions and an increase in successful attack attempts that led to obtaining the point. The number of successful attacks achieved in WL 2017 adds up to 148 as compared to 79 accomplished in RIO 2016, and the total of attempts at WL 2017 are 219 compared to 181 achieved at RIO 2016

\section{Conclusions}

Winning a rally is particular to one player and involves his full participation, using all his physical, technical, tactical and mental capacity as a whole. In the modern game, each team has a value leader, a player with remarkable qualities that stands out of the "volleyball specialist on a certain position" pattern, as it is the case with the players we have analyzed, players who have made progress in terms of the number of offensive actions and taking into account their presence in two of the world's most important volleyball events - the Olympic Games and the Volleyball World League

The high level of involvement of the players included in this study is obvious considering the number of offensive actions they carried out in the two events, but especially in the difference they recorded in the World League 2017 as compared to the 2016 Olympic Games

In the Olympic Games, the average of the passes received by the selected players was 181, out of which 84 were completed, and the number of passes at the World League showed a difference of 69 offensive actions reaching a total of 219 out of 
which 126 were completed and resulted in getting points, 42 more than at the won attacks accomplished at Rio Olympics according to Chart 4 and 5.

The selected players recorded a difference of 3.12 won attempts in the World League matches as compared to the Olympics, which indicates that wing spikers were involved in more offensive phases, an indicator that marks a number of successes compared to the number of attempts. In WL17, the average of the offensive actions completed by getting a point and service by a player is much closer to the number of attempts than those of the RIO16.

The performance of the attack and block action depended on the height at which it is executed and is related to the height of the net and it is determined by the player's ability to improve his jump height. Thus the average player height is 197.5 $\mathrm{cm}$ and it indicates that the selected players have outstanding qualities that contribute to capitalizing the attack action at the net and in the second row, through a high ball hit point $348.25 \mathrm{~cm}$, the average of the attack hits and $324 \mathrm{~cm}$ the maximum height of the jam as shown in the Chart no.3 A higher jump is essential to be able to perform an attack or strike in optimal conditions.

\section{References}

1. Reeberg S., Luiz Claudio et. al. (2008). Adaptations On Jump Capacity in Brazilian Volleyball Player Prior The Under - 19, Journal of Strength and Conditioning Research; May 2008; 22, 3;

2. José M. P.O, Manzanares P., Valadés D. (2014). Anthropometric, Physical, and Age Differences by the Player Position and the Performance Level in Volleyball, Journal of Human Kinetics volume 44/2014, 223-236

3. Rui M., José A., José Cicero M., Isabel M. (2014). Determination of attack players in high-level mens volleyball, Kinesiology, 46, 2:234-24

4. Piucco T., Santos SG. (2009). Association between body fat, vertical jump performance and impact in the inferior limbs in volleyball athletes. Fit Perf J:;8(1):9-15.

5. González-Silva J., Domínguez A. M., Fernández-Echeverría C., Rabaz F. C., Arroyo M. P. M. (2016). Analysis of Setting Efficacy in Young Male and Female Volleyball Players. Journal of Human Kinetics, 53, 189-200. 